\title{
The Varying Interpretations of Public Interest: Making Sense of Finnish Urban Planners' Conceptions
}

\author{
Sari Puustinen', Raine Mäntysalo², Karoliina Jarenko³ \\ ${ }^{1}$ Finland Futures Research Centre, University of Turku, Turku, Finland \\ ${ }^{2}$ Department of Built Environment, Aalto University, Espoo, Finland \\ ${ }^{3}$ Department of Built Environment, Aalto University, Espoo, Finland \\ Email:sari.puustinen@utu.fi,raine.mantysalo@aalto.fi,karoliina.jarenko@aalto.fi
}

How to cite this paper: Puustinen, S., Mäntysalo, R., \& Jarenko, K. (2017). The Varying Interpretations of Public Interest: Making Sense of Finnish Urban Planners' Conceptions. Current Urban Studies, 5, 8296.

https://doi.org/10.4236/cus.2017.51006

Received: February 24, 2017

Accepted: March 28, 2017

Published: March 31, 2017

Copyright $\odot 2017$ by authors and Scientific Research Publishing Inc. This work is licensed under the Creative Commons Attribution International License (CC BY 4.0).

http://creativecommons.org/licenses/by/4.0/

\begin{abstract}
During the past decades, the concept of public interest has been severely criticized. It nevertheless remains to be a key normative reference point against which public planning may be evaluated and justified. The article claims that there are multiple conceptions of public interest that coexist in everyday planning practice. These conceptions are grounded in the age-old debate on the duties of the State. In the article, four different approaches to public interest were recognized on the basis of two dimensions of the concept. These dimensions are individual/collective and regulation/non-regulation. The theoretical assumptions were tested with interview data of Finnish planning professionals. The coexistence of multiple conceptions of public interest was revealed. This ambiguity makes public interest dubious as a rhetorical tool. Without the explication of the discursive context, the concept is largely devoid of meaning. Thus, when truly seeking justification to planning decisions, with reference to "public interest", the explication of the context and the discursive framework applied is necessary.
\end{abstract}

\section{Keywords}

Public Interest, Common Good, Urban Planning, Planning Profession, State

\section{Introduction}

The concept of public interest has been debated since the birth of western de- 
mocracy. It has survived through times of criticism and enjoyed times of glory. Different eras have emphasized varying aspects of the concept and have defined it slightly differently. Each new interpretation has increased its "conceptual burden" a little more. At this point, the conception of public interest is loaded with various discursive frameworks. It has become ambiguous, to say the least, and its rhetorical strength in justifying the use of political power has been rightly questioned.

Discarding the concept of public interest is, however, problematic. Being the raison d etre of the State, it has legitimized public sector activities such as planning. The concept of public interest also provides a norm for urban planning practice, and it is also a criterion for evaluating planning and its products (Alexander, 2002: p. 227). These tasks remain to be addressed somehow-with or without the use of the concept of public interest. As Richard E. Flathman has stated, "we are free to abandon the concept but if we do so we simply have to wrestle with the problems under some other heading" (Flathman, 1966: p. 13, cited in Campbell \& Marshall, 2002a: p. 164, and Moroni, 2004: p. 165). It would be more convenient to find a way to conceptualize it in a new, more legitimate manner.

The concept of public interest has been analyzed with various frameworks in the past (Alexander, 2002; Campbell \& Marshall, 2002a; Moroni, 2004). All these constructions have emphasized and crystallized different aspects and elements of the concept. We suggest that what is characteristic to the concept of public interest in our time is indeed the coexistence of multiple discursive frameworks. These frameworks are identifiable in the prevailing political discourses, but they are grounded in the ancient debate on the duties of the State.

In this article, we elaborate on two tensions which we identify in the debate: that between the individual and the community and that between regulation and non-regulation. Placing these tensions in a matrix, we find four different conceptions of the public interest. We then test the analytical strength of our matrix with a dataset of interviews conducted among Finnish planners. All four conceptions of the public interest are identifiable in the data. We thus conclude that multiple conceptions indeed coexist both in the theoretical discussion and in everyday planning practice. The concept of public interest receives its meaning in its relation to the given discursive context, which is no longer self-evident.

Regarding our empirical focus, we have chosen to examine Finland and Finnish planners' conceptions of public interest. Being one of the Nordic (Scandinavian) welfare countries, Finland is known for the strong role of the State and strong institutional trust on public administration (Stenius, 2012; Puustinen et al., 2017). This is contrary to liberal democracies like the US, which indeed emerged from distrust in governmental authorities (Patterson, 1999: p. 1; Laurian, 2009: p. 390). In Finland, the jurisdiction of public planners is based not only on their statutory role as responsible authorities for regional and mu- 
nicipal planning but also on their role as "guarantors of public interest", as public servants who are expected to rise above the initiatives and possible conflicts between some private stakeholders (Hytönen, 2016: p. 234; Puustinen, 2006; Puustinen et al., 2017). This role, although questioned and debated repeatedly, is still relatively strong (Staffans, 2004; Leino, 2006; Puustinen, 2006; Puustinen et al., 2017).

The institutionalization of New Public Management as a mainstream mode of governance in Finland-gradually since the 1990s-has narrowed the professional autonomy of planners. They have less control over planning agendas and goals while their statutory role has remained the same and their economic responsibility has even increased. Simultaneously, the spectrum of actors and stakeholders has broadened remarkably in planning processes. Identifying the public interest has become more complicated, yet planners as a profession are still expected to warrant its presence (Puustinen et al., 2013; Puustinen et al., 2017).

\section{The Disputed Concept of Public Interest}

The concept of public interest has a long history of constant dispute. It has had numerous formulations with different emphases. The most simplistic dichotomous definition has contrasted public interest to the private one(s). In this vein, the public interest is the good of all, the good of the community, or in some interpretations the good of the majority, while the private interest is the good of a private party. This is fairly simple. The challenging part is defining how this "all" is constructed, what is "the good of the community"? Is the community simply a sum of individuals or is it an entity of its own? Is the good of the community an aggregate of individual goods, or does the community have a good as an entity? These questions have been answered differently through times, resulting in different conceptions of the public interest.

The concepts "common good" and "public interest" are sometimes used as synonyms, but they have also been used to address the questions above. "Common good" has been conceived as being something collective and indivisible, the good of the community, while "public interest" would refer to the aggregate of private interests.

Thomas Aquinas (1225-1274) pronounced the "common good" to be the goal-in fact, the raison d etre of the State. Apart from being the good of the State, common good referred also to a number of specific objectives designed to promote the good of human well-being. These objectives included peace, order, prosperity, justice, and community. The common good referred to goods that are shared and may not be reduced to private goods (Douglass, 1980). "Common good" may also be associated with a communitarian conception of politics. Communitarianism emphasizes the relations between an individual and the community, and provides an argumentative possibility for the community to have moral authority over the individual. 
The challenge with this conception comes with the definition of "the community". Ontologically, a counterargument has been made that there is no community that would exceed the sum of its parts. In the same vein, preferences are argued to always belong to individuals, meaning that there is no common good as a supra-individual value (e.g. Nozick, 1974: p. 32-33). For liberal politics, the individual is always the only moral unit. Political liberalism also rejects the idea of a comprehensive public conception of good. As far as possible, individuals are to be enabled to seek their personal conception of a good life (as long as this seeking does not harm others' respective right). The first duty of the State is to guarantee this liberty. "Good life" is a personal matter and as such does not belong to the public sphere (Rawls, 1993/1996).

Hence, in the tradition of political liberalism, "public interest" has been used to refer to a conception of common good as the aggregate of private goods. In this line of thought, the community is simply the sum of its parts. Douglass (1980) claims that the concept of public interest emerged as a reaction to the continuous wars that the national monarchies took against each other after the fall of the feudalistic regime. In the face of frequent wars and their endless need for new resources, "common good" came to be identified with the interest of the crown and the honour of the nation. Those who felt exploited did not proceed by criticizing the (mis)use of the concept of common good, but instead came up with a new one: the public interest. The claim was that it was in the public interest that citizens had the ability to develop their entrepreneurship and commerce, without having to hand all profit to the crown ${ }^{1}$.

This type of a conception of public interest has been popular in liberal politics, in which politics is first and foremost about distributing fairly the liberties and economic resources individuals need in order to lead freely chosen lives. "Common goods", such as peace and prosperity, are (theoretically) seen as reducible to individual goods and, in turn, comprehensive conceptions of a good life are not seen necessary to be discussed and shared.

Jean-Jacques Rousseau (1712-1778) provided conceptual tools to address the conflict between the common good and the public interest in his Social Contract (1762). He drew a distinction between the will of all (volonté du tous) and the general will (volonté generale). The former is the aggregate of individual wills, which may aim for "the advantage of this or that man or party" (Rousseau, 2003/1762: p. 72). The latter "considers only the common interest" (Rousseau, 2003/1762: p. 17); it refers to the will of citizens that always aim for the "advantage of the State" (Rousseau, 2003/1762: p. 72). For Rousseau, then, the key to capture what is in the advantage of the State was to think as a citizen instead of as individuals aiming at their private good. A similar idea is found in John

\footnotetext{
1"Then as now it is possible to speak of public interests and not mean only an aggregation of private interests. But the concept of interest did become popular in articulating an essentially individualistic conception of the public good, and those who used it, tended to be those who defined the ends of government chiefly in terms of the private well-being of individual citizens. They were mainly concerned about material well-being, about property and property rights" (Douglass, 1980: p. 107).
} 
Rawls' (1997) article on public reason. He writes that citizens realize the ideal of public reason by thinking "as if they were legislators" (Rawls, 1997: p. 769). Central to these notions is detaching oneself from the point of view of private advantage and examining things from the viewpoint of community ${ }^{2}$.

The ideas developed in political philosophy have been reflected in approaches to urban planning as well. Planning theory has also paid attention to the role and justification of the public planner. This justification has been grounded in the planner's role in promoting the public interest. The public interest has also provided a normative base for the planner's professional judgment (Alexander, 2002; Campbell \& Marshall, 2002b; Tait, 2011). And thirdly, the public interest has provided the criterion for evaluating the planning process and its results (e.g. Alexander, 2002).

This has placed planning professionals in a key position: the planners are considered to intrinsically understand what constitutes the public good in this and that case. There is also another side to this: the public interest is realized in part through the fact that it is precisely the public planning officers who define the public interest. Allocating the regulation of public interest to the public planners is thought to guarantee the equal treatment of all parties-equality usually considered an important element of public interest.

But times have changed and the demanding role of public planners as spokespersons of the public interest has been questioned. How are the planners to determine the public interest in the face of urban complexity and difference? Is it an issue of having one or rather several approaches to public interest? Are there mutually competing conceptions of public interest, and should they be publicly discussed (Campbell \& Marshall, 2002a)? Or is there a public interest at all?

Questioning the monolithic understanding of public interest first led to the classic liberal approach in planning: the facilitation of individual rights to strive for private interests ought be the main duty of the public officers. Lindblom's theory of incrementalist planning (Lindblom, 1959; 1965) represents this approach. Here, the achievement of win/win solutions between different "watchdogs for their interests" is seen to be the goal of planning. ${ }^{2}$ Jane Mansbridge (1998) also recognizes the division between common good and public interest. She emphasizes that this distinction did not exist in the Ancient times, but that it is an offspring of the Christian Middle Ages. "The Greeks did not, by and large, either glorify the common good or stress its difference from material advantage" (Mansbridge, 1998: p. 7). Plato, who had a particular concern for the soul, gave a deep and mystical meaning to the good (agathon). Aristotle, although not sharing this bent, also contrasted the common good with mere alliance for mutual defense or for the sake of trade and business relations. However, the distinction between the concepts on good and interest did not exist. Aristotle, for example, used the term agathon only twice in Politics. He associated koinon (common) with the word sumpheron (interest, profit, advantage). The context makes it clear that he referred to material benefit, advantage, and interest, as well as to more intangible forms of good (Mansbridge, 1998). A distinction between these two was not considered meaningful. Furthermore, the conflict between private and public goods was not emphasized either. It came about simultaneously with the development of Christianity-possibly even as an effect of Christian influence on vocabulary (see. e.g. Havelock, 1957: p. 391). The contradiction between public and private goods is one of the fundamentals of the Christian doctrine: individuals must choose between the good-meaning the public good-and the evil, i.e. selfish and private ends. 
The rise of neoliberal political ideology has added the perspective of urban economics to such aggregating of interests, bringing into discussion the concern for externalities to the so-called third parties (Thornley, 1991; Brueckner, 2011).

In turn, the communicative planning paradigm has been critical to the idea of planning as aggregation of private interests. Instead it has called for a deliberative process to determine the collective public good (Bäcklund \& Mäntysalo, 2010; Mäntysalo \& Jarenko, 2014; Puustinen et al., 2017). The planner-facilitator's role is to use his/her professional know-how and deliberative skills to shape attention and avoid misinformation in the collaborative process (Forester, 1989; Puustinen et al., 2017). This is the answer offered to address the challenge of urban complexity: participation in the decision-making procedure would increase commitment to the decision, enhancing the overall capacity of planning in managing urban life (e.g. Innes \& Booher, 2010; Wallin, 2013; Jarenko, 2013).

\section{Approaches to Public Interest}

Based on our historical overview on the approaches to the concept of public interest, we identify two key dimensions along which the different conceptions of public interest can be categorized. Firstly, the different conceptions differ in their stance towards the nature of "community". Is the public interest an aggregate of private interests or is the community postulated as an entity with an interest of its own? Liberal and individualistic conceptions of public interest do not accept the idea of community being something "supra-individual", more than the sum of its parts. Collective conceptions of public interest, on the other hand, postulate the idea of a good of the community. They either regard the public interest to refer to a "common good"-type of conception or assume that individuals are willing to assess their private interests towards a collectively justified result through deliberation. We emphasize that the collective notion does not necessarily entail a notion of supra-individual community. But it does presuppose a collective interest.

Secondly, the different conceptions vary in their level of regulation. Are individuals able to directly participate in the formulation of the public interest or is it defined by public authorities? Regulation-based conceptions give the power to define the public interest to public authorities. Non-regulation-based conceptions embrace wide inclusion in defining the public interest. It is either conceived as an aggregation of private interests or defined collectively through deliberation in the public sphere.

The regulation-based conceptions imply that it is in the public interest that a public authority defines the public good. Similarly, the non-regulation-based notions hold it to be in the public interest that the right to define the public interest is not given to a single party.

Thus we arrive at four types of public interest as four combinations of the 
individual-/collective-based and regulation/non-regulation-based dimensions (Table 1$)^{3}$.

\section{Individual- and non-regulation-based public interest}

Conceptions of public interest found in the upper-right corner of our matrix, take private interests as a starting point, and identify the public interest through adding them up. The public interest, then, is not a joint notion and it is not about collective preference. It is the aggregate of the private preferences of the stakeholders in a particular case. This notion of public interest would correlate with reliance on market rationality: the "invisible hand" of the presumably free urban markets would determine through popular consumer choices the public interest, without regulative interference by the public planners.

\section{Individual- and regulation-based public interest}

Conceptions of public interest found in the upper left corner of our matrix typically concern the regulation of individual aspirations for the private good. These conceptions follow the basic principle of political liberalism: enabling each individual to strive for one's conception of good life as far as this striving does not harm others' respective right. Regulation is needed to prevent or minimize the negative externalities of these private aspirations, to prevent harm to others. What may from a private actor's point of view be an optimal decision, may prove sub-optimal from the societal point of view. Examples of this type of public interest are regulation of urban growth to afford public parks for recreation, and regulation of private car use to prevent congestion, air pollution, and loss of traffic safety (Brueckner, 2011).

\section{Collective- and regulation-based public interest}

Collective-regulated conceptions of public interest (bottom-left) focus on the collective good. Parks and technical infrastructure are examples of the collective good, and they are often provided and maintained by public authorities. What is important here is that these goods are also defined by public authorities-for example, plans define networks of technical infrastructure and locate parks. This

Table 1. Approaches to public interest.

\begin{tabular}{lcc}
\hline & Regulation-based & Non-regulation-based \\
\hline Individual-based & Concern for externalities & Aggregation of private interests \\
Collective-based & $\begin{array}{c}\text { The good of the community } \\
\text { determined by the public authority }\end{array}$ & $\begin{array}{c}\text { The good of the community determined } \\
\text { through deliberation in the public sphere }\end{array}$ \\
\hline
\end{tabular}

\footnotetext{
${ }^{3}$ Alexander (2002: p. 229) and Campbell and Marshall (2002a: p. 174) categorize the different conceptions of public interest according to the distinction between procedural and substantive aspects. The first refers to the identification of public interest with the decision making or planning process, and the latter with the content and outcome of decisions and plans. We chose not to base our matrix on this distinction, but this does not mean that our conceptual analysis would be in contradiction with the work of the above planning theorists. The identified procedural and substantive types of the concept of public interest can indeed be located in our matrix. Let us take Campbell and Marshall's classification of public interest concepts according to procedural and substantive categories: their procedural conceptualizations include rights-based and dialogical approaches, whereas their substantive ones include concepts based on utilitarianism and modified utilitarianism, as well as the unitary approach (Campbell and Marshall, 2002a: p. 174). Table A (See: Appendix) aims to locate the two procedural and the three substantive types of public interest to our matrix.
} 
category is inspired by the idea of a community as a supra-individual entity. It is possible to understand the collective good as (at least theoretically) reducible to private goods, as the liberal argument claims. For example, it is my private advantage to have access to clean tap water at my home. In this category the public good is, however, collective by nature: it is used collectively and it is not provided for any private party alone. This approach to public interest corresponds with the modernist tradition of regulative planning.

\section{Collective- and non-regulation-based public interest}

Conceptions of public interest that fall in the last category (bottom-right) are collective by nature, but also collectively defined and regulated. This means active participation, deliberation in the public sphere. This category is again inspired by the idea of a supra-individual community, but does not necessarily require the postulation of one. Rousseau demanded the participants in deliberation to think as citizens, i.e. with the good of the State in mind. The same claim was forwarded by early deliberative democracy theorists (Rawls, 1993/1996; Habermas, 1996; Cohen, 1998). More recent conceptions of deliberation, however, allow for participants to forward private interests as long as this is done in mutual respect and with the aim of finding a collectively satisfying result (Gutman \& Thompson, 1996, 2004; Bohman, 1998; Hendriks, 2006). The issues under deliberation are collective, because in the liberal context private matters are not to be taken to the public sphere. This definition of "collective issue" allows for a wider range of issues to be collectively discussed than the definition based on collective use (as in the previous category). This approach to public interest corresponds with the ideals of communicative planning.

We will use the above matrix of four conceptions of public interest in our analysis of interview data of Finnish planners, to which we will now turn.

\section{Finnish Planning Professionals' Conceptions of Public Interest}

The empirical data on the Finnish planners' views of public interest was collected in November-December 2012. The interviews were part of a research project dealing with the sufficiency of human resources in Finnish municipal and regional planning and related state guidance, as regulated by the Land Use and Building Act (LUBA) (Puustinen et al., 2013). In the background there are both efforts of the Finnish government to increase governmental productivity, and a gradual change of municipal governance towards New Public Management.

In Finland, the land use planning system is clearly defined by the LUBA and strongly run by public authorities (the Act enabling some local variations, though). The land use planning system is hierarchical: the higher level plans steer the lower level plans. The system has three levels of land use plans with a clear division of labour between them: the regional land use plan, the local master plan and the local detailed plan.

On the top of the hierarchy there are the National Land Use Guidelines defined by the Government. They should be taken into account throughout the 
country at all levels of land use planning, but, in practice, they are implemented mainly through regional plans. The regional plans are drawn up and approved by regional councils. The regional council (there are 18 of them) is the region's statutory joint municipal authority. The purpose of the local master plan is to offer a general long term guideline for the municipality's land use. It is prepared and approved by the local (municipal) government. The purpose of the local detailed plan is to determine the characteristics of local districts and sites, in direct control of development, including the use of buildings, their allowed floor space, building types and styles, number of floors etc. It is also prepared and approved by the local government. In addition to municipal and regional planning authorities, there is a regional representative of the state involved, to supervise planning. Finland's Centres for Economic Development, Transport and the Environment (CEDTEs) conduct the regional implementation and development tasks of the state administration. There are 15 regional centres to guide and advise land use planning both at the regional and the municipal level.

For this study, 16 land use planning authorities were interviewed, five of them being land use planning executives in large ${ }^{4}$ cities, five being regional planning executives and six being heads of land use departments in CEDTEs. All interviewees were in a leading position and they had a long experience in land use planning. Interviews were made in five cities (Oulu, Turku, Tampere, Seinäjoki, Lahti), each being the central city of its region. The interviewees from Regional Councils and CEDTEs were chosen from those regions where the cities are. The interviewees from the case cities know each other well and cooperate a lot.

The half-structured interviews were recorded and transcribed. Concerning the public interest, the interviewees were asked the following questions:

- Does the public interest exist?

- What does the public interest mean?

- Is the purpose of land use planning to implement the public interest?

- Who is in charge of defining the public interest in planning?/Where does the public interest come from?

- Through which kind of process should the public interest be defined?

- Have the ideas and conceptions of public interest changed during the interviewee's career?

All interviewees shared the view that the public interest is involved in planning and that it is the purpose of planning to implement and promote the public interest. In addition, interviewees saw themselves as representatives and promoters of the public interest in planning processes. One person, being one of the youngest interviewees, had a slightly skeptical view of the existence of the public interest. Yet, he commented: "We often compromise in land use planning and everybody is equally dissatisfied. If you call that public interest, it exists".

In turn, defining the content or meaning of public interest was more complicated. The answers varied but there were interesting similarities, too. We tested the analytical capacity of the above matrix of public interest types by mapping all

${ }^{4}$ Large in the Finnish scale, with population ranging from 60,000 to 220,000 . 
comments and opinions of each interviewee with it.

Each interview was handled as an independent case. In one case there were exceptionally two interviewees - two colleagues from the same office - present. Their opinions have been merged. Altogether, there were 15 interviews. In the analysis, the views of public interest were categorized in the matrix (Table 2). The unit of observation was, depending on the situation, a sentence, a couple of sentences, or a short, descriptive example or a story.

Figure 1 presents the mapping of all interviews as individual units. Horizontally, in the top row of cases are the city planners, in the middle row are the representatives of regional councils and in the bottom row are the representatives of the Centres for Economic Development, Transport and the Environment (CEDTEs). In the vertical direction, the interview units are ordered according to the five cities/regions.

The mapping of opinions shows that every interviewee brought out several different dimensions of public interest. That is, in each interview one can recognize references to several debates in the history of ideologies and to different approaches to public interest. Thus, the interviewees' perceptions of public interest were not one-dimensional.

Table 2. Examples of classified pieces of data.

Regulation-based
Concern for externalities:
"Public interest is an essential thing in planning. It is related to
democracy and equality. Generalizing, there is somebody who
wants to build as big and high as possible... but public interest
takes parks and public spaces into account". (city planner 2)
"City dwellers must have equal access to the good environment"
(regional planner 4)

Individual-based

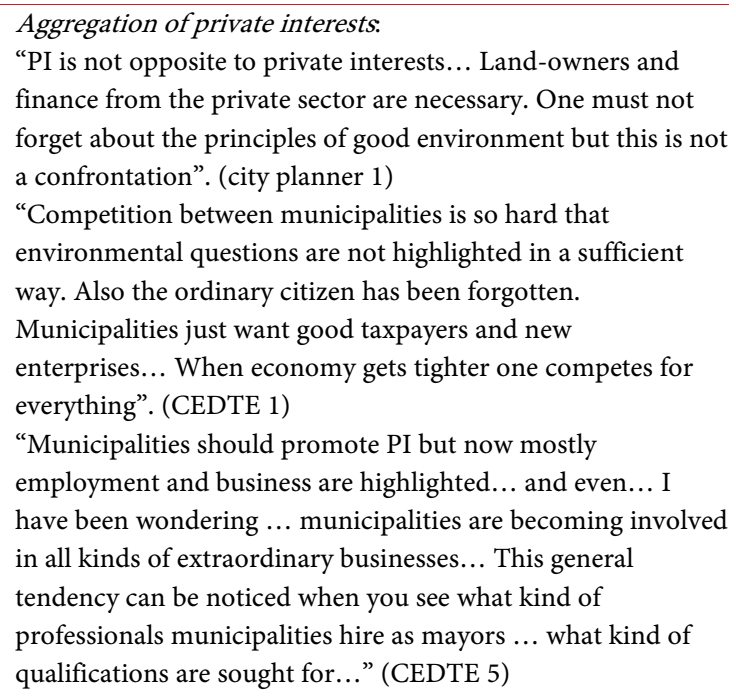

"PI is not opposite to private interests... Land-owners and finance from the private sector are necessary. One must not forget about the principles of good environment but this is not a confrontation". (city planner 1)

"Competition between municipalities is so hard that environmental questions are not highlighted in a sufficient way. Also the ordinary citizen has been forgotten. Municipalities just want good taxpayers and new enterprises... When economy gets tighter one competes for everything". (CEDTE 1)

"Municipalities should promote PI but now mostly employment and business are highlighted... and even... I have been wondering ... municipalities are becoming involved in all kinds of extraordinary businesses... This general tendency can be noticed when you see what kind of professionals municipalities hire as mayors ... what kind of qualifications are sought for...” (CEDTE 5)

The good of the community determined by the public authority. "From my point of view, the whole planning system tells about PI... PI has something to do with sustainable development and future generations. Developers, politicians, loud-speaking neighbours, all kinds of professionals, they can speak for The good of the community determined through deliberation in the public sphere:

"PI exists when we discuss about values openly. Big projects are carried out, often aiming to improve competitiveness and entrepreneurship, but we don't do it without values... One themselves. But future generations cannot; silent and poor people must think about PI; we must discuss and communicate". Collective-based cannot... One must consider everybody's interest... And of course, business and city development must be taken into account, too... And if we have an even broader point of view, climate change must be considered... So I understand PI as everybody's, all city-dwellers' interest". (city planner 2)

"Sometimes one (a planner) comes to a situation when one must promote PI by reminding about the whole". (regional planner 1) 


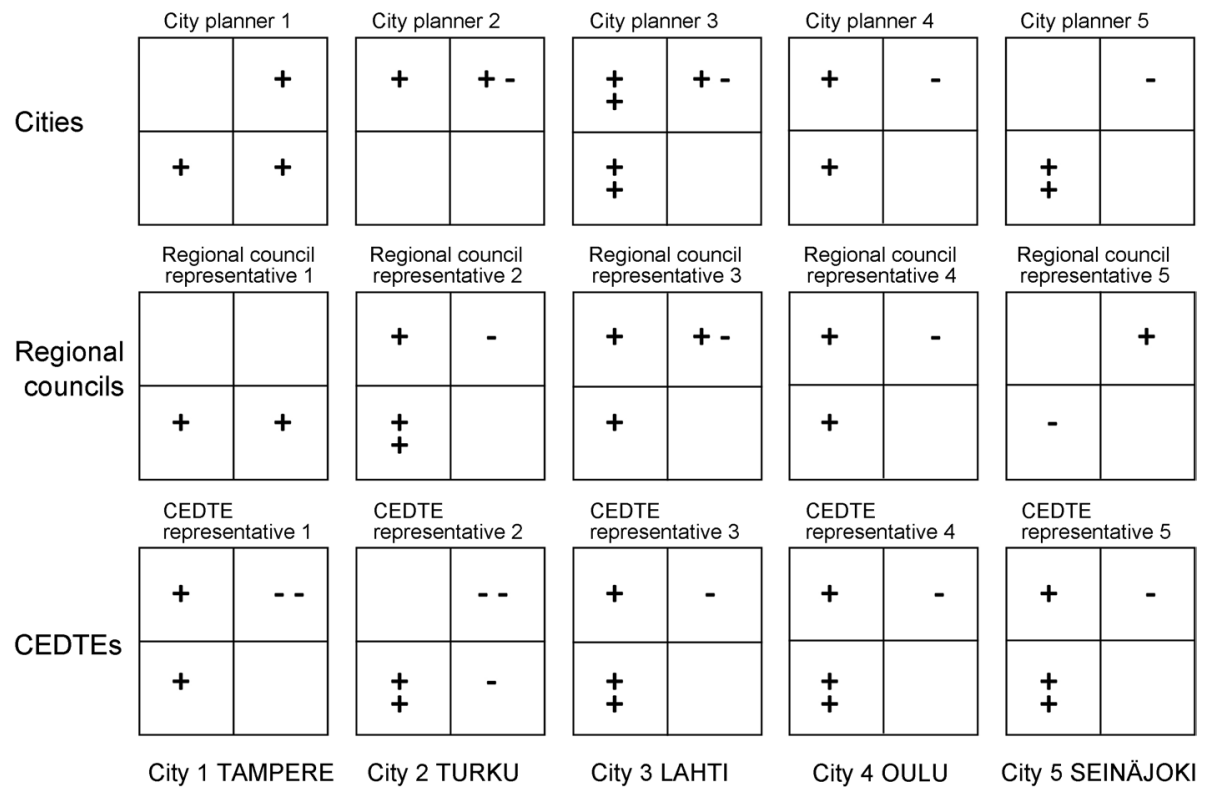

Figure 1. Each interviewed planner's definitions of public interest as mapped in the matrix, with the interviewee's position identified according to his/her organization and city/region. (Sign $(+)$ indicates where the interviewee's definition of PI was located in the matrix. Sign $(++)$ indicates strong identification of the interviewee's opinion in the given matrix location. Sign (-) indicates the location of the interviewee's recognition of a public interest definition, to which the interviewee him/herself has a negative attitude. Sign (--) indicates the location of the interviewee's recognition of a public interest definition, to which the interviewee him/herself has a strong negative attitude).

Normative statements were typical. For example, it was pointed out that in contemporary municipal planning private interests have become prioritized at the cost of public interest, but that it should be vice versa.

Moreover, the figure reveals differences and similarities between the emphases of the interviewees. The public interest as "regulation-based" is more emphasized (in a positive light) than as "non-regulation-based". It is especially emphasized among the representatives of the CEDTEs. Thus, it can be interpreted that the view of public interest as authority-regulated is even more favoured among state authorities than city planners or regional planners. This is not surprising considering the role of CEDTEs as regional level state supervisors and overseers of municipal and regional planning. Further, it can be interpreted that city planners and regional planners are slightly more willing to approach public interest from the perspective of private interests and individualistic stances. This, in turn, is probably a reflection of the tightening municipal economy and the ongoing competition for private investments between municipalities.

The scarcity of picks in the category of "deliberation in the public sphere" is worth noticing. Only two interviewees out of 16 stated that the public interest should be defined case by case through a public discussion. One interviewee commented critically that citizen participation is against the public interest because it gives too much attention to private interests, loud persons and to NIMBYism. 


\section{Discussion and Conclusion}

The concept of public interest has been both analyzed and criticized from various viewpoints in the past. Despite the criticism, the theoretical interest in the concept has not vanished (e.g. Campbell \& Marshall, 2002a; Moroni, 2004; Alexander, 2002; Sager, 2013; Mäntysalo \& Jarenko 2014; Puustinen et al., 2017). In this article, we offer our contribution a conceptual matrix by which the contemporary heterogeneity of the conceptions of public interest in planning can be analyzed. The components of our matrix have been identified in previous planning theoretical research (see Endnote iii) but their combination in the matrix is novel. As a conclusion to our theoretical review and analysis of empirical data, we claim that multiple conceptions of public interest co-exist in our time. We claim further, that the four conceptions that we have identified are not merely contemporary. Instead, they stem from age-old philosophical and political scientific aspirations to determine the good of the society and good human life, and the role of the State in advancing them. With our conceptual matrix we hope to have revealed this historical link, too.

In the interviews of the Finnish planners, all the four notions of public interest were voiced, and the planners often used several of them during a single interview. Although our interview data are far from extensive, we consider it sufficient for indicating the multiplicity of public interest conceptions among Finnish planners, and the analytical feasibility of our conceptual matrix in sorting these out. An interesting-although not very surprising-revelation was that those who favored the collective- and regulation-based notion of public interest, tended to regard the individualistic non-regulated conception as undesirable, and vice versa.

The co-existence of various public interest conceptions can make the concept a dubious rhetorical tool in planning practice. Without the explication of the discursive context, the concept is devoid of meaning. Thus, when truly seeking justification to planning decisions by appealing to public interest, its discursive context has to be explicated. Otherwise the concept could be used to promote contradictory normative purposes, even without the user's awareness of these contradictions. Defining the context in relation to its discursive framework then becomes key in identifying what is being conceived as the public interest and what is being promoted by its use. Whether the planning situation at hand calls for an individualistic or a collectivist approach, or more or less regulation, is an issue to be debated and justified, beyond referring to public interest as a mere label. How to use the notion of public interest in justifying choices in public planning is indeed difficult with such a contested concept, and yet public planning is bound to its use, or to wrestle with the problems of justification under another heading, as Flathman noted. But when multiple conceptions of public interest are found to coexist in planning practice, as in our study on Finland, the problem reaches another level. Then it is no longer a question of how to justify with reference to the public interest, but also what it really is that is being justified by the use of the concept. Aspirations to find solid ground for the justifica- 
tion of public planning must continue.

\section{Acknowledgements}

The authors would like to thank the Academy of Finland and the Finnish Ministry of Environment for their support. Writing and publishing the article were financed by the Academy of Finland (project no. 138759 \& 303538).

\section{References}

Alexander, E. R. (2002). The Public Interest in Planning: From Legitimation to Substantive Plan Evaluation. Planning Theory, 1, 226-249. https://doi.org/10.1177/147309520200100303

Bohman, J. (1998). Survey Article: The Coming of Age of Deliberative Democracy. The Journal of Political Philosophy, 6, 400-425. https://doi.org/10.1111/1467-9760.00061

Brueckner, J. K. (2011). Lectures on Urban Economics. Cambridge, MA: The MIT Press.

Bäcklund, P., \& Mäntysalo, R. (2010). Agonism and Institutional Ambiguity. Ideas on Democracy and the Role of Participation in the Development of Planning Theory and Practice-The Case of Finland. Planning Theory, 9, 333-350. https://doi.org/10.1177/1473095210373684

Campbell, H., \& Marshall, R. (2002a). Utilitarianism's Bad Breath? A Re-Evaluation of the Public Interest Justification for Planning. Planning Theory, 1, 163-187. https://doi.org/10.1177/147309520200100205

Campbell, H., \& Marshall, R. (2002b). Values and Professional Identities in Planning Practice. In P. Allmendinger, \& M. Tewdwr-Jones (Eds.), Planning Futures: New Directions for Planning Theory (pp. 93-109). London: Routledge.

Cohen, J. (1998). Democracy and Liberty. In J. Elster (Ed.), Deliberative Democracy (pp. 185-231). Cambridge: Cambridge University Press. https://doi.org/10.1017/cbo9781139175005.010

Douglass, B. (1980). The Common Good and the Public Interest. Political Theory, 8, 103-117.

Flathman, R. E. (1966). The Public Interest: An Essay Concerning the Normative Discourse of Politics. New York: Wiley.

Forester, J. (1989). Planning in the Face of Power. Berkeley, LA: University of California Press.

Gutman, A., \& Thompson, D. (1996). Democracy and Disagreement. Cambridge, MA: The Belknap Press of Harvard University Press.

Gutman, A., \& Thompson, D. (2004). Why Deliberative Democracy? Princeton, NJ: Princeton University Press. https://doi.org/10.1515/9781400826339

Habermas, J. (1996). Between Facts and Norms, Contributions to a Discourse Theory of Law and Democracy. Cambridge, MA: The MIT Press.

Havelock, E. A. (1957). The Liberal Temper in Greek Politics. New Haven, CT: Yale University Press.

Hendriks, C. M. (2006). Integrated Deliberation: Reconciling Civil Society's Dual Role in Deliberative Democracy. Political Studies, 54, 486-508.

https://doi.org/10.1111/j.1467-9248.2006.00612.x

Hytönen, J. (2016). The Problematic Relationship of Communicative Planning Theory and Nordic Legal Culture. Planning Theory, 15, 223-238. 
https://doi.org/10.1177/1473095214549618

Innes, J. E., \& Booher, D. E. (2010). Planning with Complexity: An Introduction to Collaborative Rationality for Public Policy. Oxford: Routledge.

Jarenko, K. (2013). The Local Co-Governance Approach in the Herttoniemi Neighbourhood as a Deliberative System. In L. Horelli (Ed.), New Approaches to Urban Planning. Insights from Participatory Communities (pp. 45-64). Helsinki: Aalto University.

Laurian, L. (2009). Trust in Planning: Theoretical and Practicextental Considerations for Participatory and Deliberative Planning. Planning Theory \& Practice, 10, 369-391. https://doi.org/10.1080/14649350903229810

Leino, H. (2006). Kansalaisosallistuminen ja kaupunkisuunnittelun dynamiikka [Citizen Participation and the Dynamics of Town Planning] (p. 1134). Tampere: University of Tampere.

Lindblom, C. E. (1959). The Science of Muddling through. Public Administration Review, 19, 79-88. https://doi.org/10.2307/973677

Lindblom, C. E. (1965). The Intelligence of Democracy. New York, NY: The Free Press.

Mansbridge, J. (1998). On the Contested Nature of the Public Good. In W. W. Powell, \& E. S. Clemens (Eds.), Private Action and the Public Good (pp. 3-19). New Haven, CT: Yale University Press.

Mäntysalo, R., \& Jarenko, K. (2014). Communicative Planning Theory Following Deliberative Democracy Theory: Critical Pragmatism and the Trading Zone Concept. International Journal of E-Planning Research, 3, 38-50. https://doi.org/10.4018/ijepr.2014010104

Moroni, S. (2004). Towards a Reconstruction of the Public Interest Criterion. Planning Theory, 3, 151-171. https://doi.org/10.1177/1473095204044779

Nozick, R. (1974). Anarchy, State and Utopia. New York, NY: Basic Books.

Patterson, O. (1999). Liberty against the Democratic State: On the Historical and Contemporary Sources of American Distrust. In M. E. Warren (Ed.), Democracy and Trust (pp. 151-207). Cambridge: Cambridge University Press. https://doi.org/10.1017/cbo9780511659959.006

Puustinen, S. (2006). Suomalainen kaavoittajaprofessio ja suunnittelun kommunikatiivinen käänne. Vuorovaikutuksen liittyvät ongelmat ja mahdollisuudet suurten kaupunkien kaavoittajien näkökulmasta [The Finnish Planning Profession and the Communicative Turn in Planning]. Espoo, Yhdyskuntasuunnittelun tutkimus-ja koulutuskeskuksen julkaisuja A 34, Teknillinen korkeakoulu.

Puustinen, S., Hirvonen, J., Niemi, P., \& Mäntysalo, R. (2013). Selvitys alueiden- käytön suunnittelun ja ohjauksen voimavaroista [Report on the Resources Available for Land Use Planning and Guidance]. Helsinki: Ympäristöministeriön raportteja 22. https://doi.org/10.1080/14649357.2016.1245437

Puustinen, S., Mäntysalo, R., Hytönen, J., \& Jarenko, K. (2017). The "Deliberative Bureaucrat": Deliberative Democracy and Institutional Trust in the Jurisdiction of the Finnish Planner. Planning Theory \& Practice, 18, 71-88.

Rawls, J. (1993/1996). Political Liberalism. New York, NY: Columbia University Press.

Rawls, J. (1997). The Idea of Public Reason Revisited. The University of Chicago Law Review, 64, 765-805. https://doi.org/10.2307/1600311

Rousseau, J.-J. (2003/1762). On the Social Contract. Mineola, NY: Dover Publications.

Sager, T. (2013). Reviving Critical Planning Theory. Dealing with Pressure, Neo-Liberalism, and Responsibility in Communicative Planning. London: Routledge.

Staffans, A. (2004). Vaikuttavat asukkaat. Vuorovaikutus ja paikallinen tieto kaupunki- 
suunnittelun haasteina [Influential Residents. Interaction and Local Knowledge Challenging Urban Planning and Design]. Espoo, Yhdyskuntasuunnittelun tutkimus-ja koulutuskeskuksen julkaisuja A 29. Teknillinen korkeakoulu.

Stenius, H. (2012). Paradoxes of the Finnish Political Culture. In J. P. Árnason, \& B. Wittrock (Eds.), Nordic Paths to Modernity (pp. 207-228). New York, NY: Berghahn Books.

Tait, M. (2011). Trust and the Public Interest in the Micropolitics of Planning Practice. Journal of Planning Education and Research, 31, 157-171. https://doi.org/10.1177/0739456X11402628

Thornley, A. (1991). Urban Planning under Thatcherism. London: Routledge.

Wallin, S. (2013). Urban Complexity Challenging Urban Planning. In L. Horelli (Ed.), New Approaches to Urban Planning. Insights from Participatory Communities. Helsinki: Aalto University.

\section{Appendix}

Table A. Campbell \& Marshall's (2002a) categorization of the concept of public interest, based on the distinction between substantive and procedural concepts, as located to our matrix of approaches to public interest.

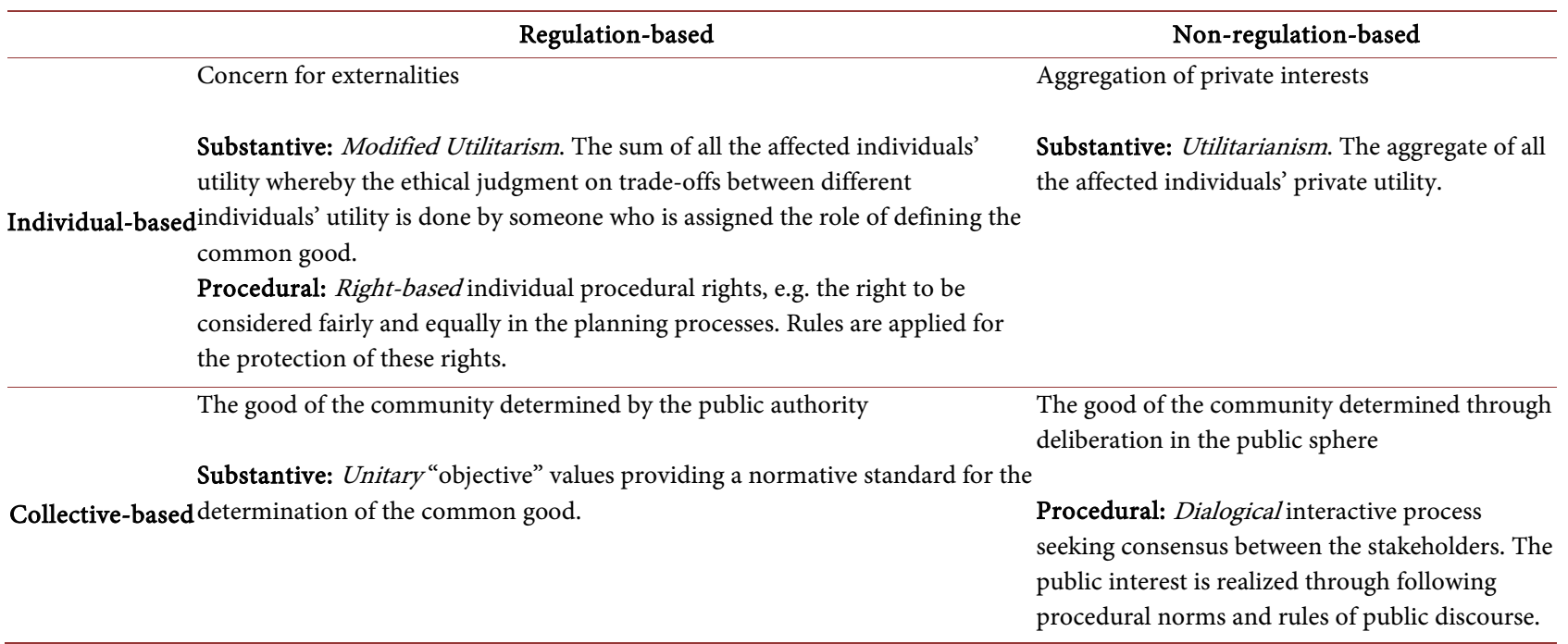


Submit or recommend next manuscript to SCIRP and we will provide best service for you:

Accepting pre-submission inquiries through Email, Facebook, LinkedIn, Twitter, etc. A wide selection of journals (inclusive of 9 subjects, more than 200 journals)

Providing 24-hour high-quality service

User-friendly online submission system

Fair and swift peer-review system

Efficient typesetting and proofreading procedure

Display of the result of downloads and visits, as well as the number of cited articles Maximum dissemination of your research work

Submit your manuscript at: http://papersubmission.scirp.org/

Or contact cus@scirp.org 